\title{
On the Path of Learning Party Organization Leading the Construction of Study Style
}

\author{
Chen $\mathrm{Yu}$ \\ Shandong Technology and Business University \\ Yantai, Shandong, 264005, China
}

\begin{abstract}
The learning party organization and the study style construction are complementary and inseparable. The learning party organization requires each sub party organization to study conscientiously and practice the theoretical system of socialism with Chinese characteristics and to learn the knowledge necessary for modernization. The excellent style of study is an important guarantee for the training of socialist constructors and successors. And the university is the key period of the growth of students. However, students' ideals and beliefs are weak; the teaching supervision is not perfect; students are not active in learning; the influence of social unhealthy thoughts on the style of study leads to discrimination ability of students; the students have incorrect learning attitude and rely too much on the network. With the above problems, this article is targeted at continuous strengthening of party construction at the grassroots level, improving the education management system for party members, giving full play to the exemplary role of party members, carrying forward advanced models through multiple channels, improving campus culture, strengthening teachers' morality. By carrying out these measures, effectively strengthen the construction of learning party organizations, and pave the way for study style construction.
\end{abstract}

Keywords-learning-oriented; party organization; study style construction

\section{INTRODUCTION}

The report of the 19th National Congress of the Communist Party of China stressed that to guide the socialist country with a large population of more than 1.3 billion people, the communist party of china must be both politically sound and capable. It is necessary to enhance its learning skills and create a strong atmosphere of learning and practice in the whole party. Construct itself as a Marxist learning-oriented party and promote the building of a big country of learning [1]. In the Fourth Plenary Session of the 17th CPC Central Committee, the major strategy of building a Marxist political party was proposed. It was pointed out that building learning-oriented party organizations at all levels is the basic project for building a Marxist learning-oriented political party. The "Opinions on Advancing the Construction of Learning Party" issued by the General Office of the CPC Central Committee pointed out that it is necessary to vigorously create and form a strong atmosphere where everyone appreciate learning, advocate learning, and persist in learning. We should call on all party members to study throughout the life. Establish and improve an effective learning mechanism, so that the party member can improve their learning abilities and literacy, and play exemplary roles. All these can contribute to the enhancement of the party's creativity, cohesiveness and combat effectiveness [2].

President Xi Jinping once said that young people are in the period of formation and establishment of values, so it is very important to well develop their values in this period. University is critical for the formation of values. A good academic style plays an unelectable role in guiding young people to establish a correct world outlook, values, and outlook on life, develop a scientific way of thinking, establish the concept of learning throughout life, and grows into the talent with ambition, morality, knowledge and discipline. In the construction of the study style, we should give full play to the exemplary role of the faculty and staff members and student party members. Let them take an initiative so as to drive all teachers and students to establish correct learning attitudes, develop good study habits, build an excellent study style in the university, and promote the growth of teachers and students.

\section{The SignificAnCE OF LEARNING PARTY ORGANIZATION TO THE CONSTRUCTION OF ACADEMIC} ATMOSPHERE

\section{A. Learning Party Organization is the Political Guarantee of the Construction of Academic Atmosphere}

The faculty and staff party branch and the student party branch are the main force of the learning party organization. College teachers, especially those who are party members, are high-quality talent representatives with firm political stand, courage to develop and innovate, awareness of combining theory and practice, and entrepreneurship. They play a leading role in guiding students to study the socialist theoretical system with Chinese characteristics. Only by becoming communicators of advanced ideology and culture, and unswerving supporters of the party's ruling, can teachers better take responsibility for the healthy growth of students. The student party branch is composed of advanced youth. The party construction plays an important political guiding role in students' ideological and political education. As student party members are the models for students, strengthening the faculty and staff party organization construction and the student party branch construction can improve the political awareness of students. It is necessary to give full play to the party's political and organizational advantages, and to pass on the advanced, systematic, scientific and evolving party theory to every young student through primary party organizations. 


\section{B. The Construction of Study Style is the Carrier for the Learning Party Organization to Exert Its Effectiveness}

Excellent academic atmosphere manifests the good learning effect of the learning-orientated party organization. Therefore, we need to implement the learning tasks of the party organization through various forms, develop the party into a high-quality team, and further facilitate the form of academic atmosphere with the learning-type party. Skilled teachers should help new ones and the party members should help each other, so that the young teachers will actively approach the party. In this way, we can take in the outstanding teachers with great teaching ability and scientific research ability, so that our party can become a highly intensive learning party with excellent talents. Moreover, we can promote the formation of a good teaching and academic atmosphere among teachers by improving political quality and theoretical literacy. The absorption of students with firm political stance, excellent academic performance and high comprehensive quality into the party organization can play a correct guiding role, which means that the student party members can take the lead in all aspects, thus promoting the sound development of the study style. In the construction of the style of study, teachers, party members, and party organizations should be regarded as important supporting carriers, and the learning party organization should be regarded as an important fighting bastion [3]. We need to give full play to the leading role of party members and the powerful role of party organizations' cohesiveness and centripetal force, and take the construction of learning-type party as an opportunity to promote the formation of a fine academic style.

\section{Problems IN The Construction OF ACAdemic ATMOSPHERE IN COLLEGES AND UNIVERSITIES}

College students in the new era are active in thinking, broad-minded, and ambitious. They acquire new knowledge, master new skills, and accept new ideas very quickly. However, with the development of society and the challenges that higher education faces, there emerge some problems concerning college students. First, due to the large amount of information from different sources, students' ability to distinguish what is right is weakened. The diversification of the world and the normalization of modern science and technology have enabled college students more easily connect with the world and quickly access new things. But at the same time, there have been some bad statements violate national policies and disseminate wrong values, as well as cyber fraud, and telecom fraud. Due to the lack of social experience and the ability to distinguish between right and wrong, some students whose thoughts are filled with idealization, are deceived or induced by wrong thoughts, and even manipulated by criminals to violate national laws and regulations. Second, having been influenced by some wrong values, some students do not have good attitudes towards learning without motivation, and their ideals and beliefs are not firm enough. What's worse, some students go to college because of pressure from their parents or ambient pressure, or just for a diploma [4]. Learning without plans or goals leads to unorganized disciplinary, such as late for class, early leave, skip class and truancy. Some students went to college spending their time on enjoying instead of learning.
Third, science and technology also bring the negative impact on students. According to the survey, mobile phones and the Internet have become a necessity for college students to learn. On the one hand, thanks to the openness of the Internet, college students can access information anytime and anywhere. On the other hand, the convenience of the network also makes college students indulged in the network and gradually lose their autonomy in learning. This makes the previous rigorous, diligent campus atmosphere become sloppy. People who respect academy become lazy, and opportunistic [5].

The rapid development of science and technology has also brought great impact on the education for college teachers. Although the classroom becomes lively with the transformation from the traditional blackboard board to the network multimedia teaching, multimedia teaching poses a huge challenge to teachers and their knowledge reserves. A survey of the arts faculty in a university shows that some students complain that the multimedia courseware of the teachers is unvaried, and the actual cases of the chapters are old and outof-date; some teachers in the course only repeat what the textbook say without knowledge expansion. In this context, students cannot actively participate in the course, causing the depressed classroom atmosphere, and weak learning enthusiasm of students.

It can be seen that although the construction of academic style plays an important role in the construction and development of colleges and universities, the diversity of society and the individualization of students impede the construction of the academic style, causing the above problems in the specific operation and practice. These problems in turn restrict the construction of the style of study. Therefore, guided by the connotation of the learning-type party, we will unify strategic thinking, make overall plans, build a variety of intermediate platforms, broaden the scope of study, and improve the safeguard mechanism, so as to effectively promote the study style of higher education institutions [6] .

\section{Reasons for the Status QuO OF COLLEGE StUdy STYLE CONSTRUCTION}

\section{A. Weak Ideals and Beliefs}

As far as university teachers are concerned, although daily teaching activities are important work content, they also face great pressure brought by scientific research. After the teaching activities, most of the teachers are devoted to scientific research, leaving insufficient energy to innovate the curriculum, and the sense of responsibility of teachers' imparting and disabuse is gradually weakened. As far as college students are concerned, they have not combined the destiny of the country with their own destiny, and have not recognized their historical mission and responsibilities. As a result, learning is not regarded as an important channel for realizing the life value and empowering oneself.

\section{B. Imperfect Teaching Supervision}

At the school level, the lack of standardized teaching management has hindered the construction of the style of study. For example, the teaching effect of the first classroom and the 
second classroom lacks reward and punishment system and assessment system; the curriculum arrangement is unreasonable; classroom teaching and social practice cannot coordinate effectively; teaching facilities resources are in adequate. At the teacher level, the introduction of professional prospects is not comprehensive. The disorder of teaching and the lack of daily academic guidance are also the obstacles in the construction of the study style. At the student level, they may be unfamiliar with the teaching order, and have a fragile knowledge base with little professional knowledge.

\section{Lack of a Sense of Active Learning}

On the one hand, the change of the learning environment has transformed students' passive learning to active learning. Students who are new to the university show their inadaptability in learning, such as lack of motivation, impetuous learning attitude, shallow understanding of the profession, and unclear of career development. On the other hand, limited self-coordination restricts student learning. In order to improve personal capability, most students will join the student organization. The variability of the external environment forces the students to spend more time and energy on campus activities at the cost of the campus learning.

\section{The Influence of Unhealthy Social Thoughts on the Style of Study}

The social hedonism, egoism, extravagance, utilitarianism and other bad ideas gradually infiltrated into the campus, which affected the construction of academic style, and also seriously affected the campus culture and the establishment of students' learning goals. Without proper guidance, facing with diversified values, students are prone to lose their ability to distinguish and cannot reasonably plan their life [7], affecting the formation of their own correct values and the mastery of basic skills that are need to enter the society.

\section{The Effective Way for Learning-Oriented Party ORGANIZATION TO GUIDE THE CONSTRUCTION OF STYLE OF STUDY}

\section{A. Constant Enhancement on the Grass-Roots Party Construction}

The school leadership is supposed to think highly of the linkage effect of grass-root party construction on style of study construction. Based on the academic atmosphere construction, the long-term work directions for each department shall be arranged as a whole, periodic target and assessment mechanism as well as a good communication among all sectors shall be established. Also the party construction should be combined with students' management, teaching management and educational instruction process. In daily education, study and work, party members are responsible to play their political leading roles to spread advancing theory of socialism with Chinese characteristics for the faculties and students to cultivate firmly political quality, improve the cohesion and power of learning-oriented party organization, strengthen the capacity of anti-corruption and change resistance, overcome utilitarianism and get rid of the confusion in life and work. One of the main functions for college and university counselors is the first fighter to instruct students about ideology and politics. The counselors not only play an essential role in constructions of students' party branches, students' applicant for party membership and students' party membership building, but also stand as a powerful force for style of study construction. Besides, the whole school focuses on the building of counselor team and makes it professional and occupational for exert its main force in party construction for well construction of study atmosphere.

\section{B. Perfection on Development, Education and Management System for Party Members}

Pursuant to strict development procedure of party members and rigorous enrollment monitor, only those who are in high political consciousness with excellent professional ability, upright and honest manners, outstanding grades, lofty morality and sentiment and well comprehensive quality can be admitted to party. As closely abide by the disciplines and requirement, the developing member should be punished timely and properly if they fail to understand the importance of training and comply with the training requirements, whereby to put an end to the source of thoughts corruption. very member obliges to be consistent with party central committee and learn national policies and regulations and party theories; carry forward the fine traditions during the material statutory holidays; to explore new knowledge in professional fields with specialty; to innovate the pattern for member education and organize various practical activities to highly unify the members' development and instruction to form a effective mechanism.

\section{Full Exertion of Pioneering and Model Functions of Party Members}

The faculty members are supposed to take part in the study of political theories in the school to make good use of the advancement and initiatives of party members, and arouse enthusiasm for work and fulfill the party principles with practices. When doing duties, the faculty also needs to enrich their knowledge, improve their qualities, treat students with benevolence and become a guide for students in their life. As a stalwart, every faculty member takes responsibility to promote the party when they stand in it and gradually spread advancing theories and knowledge to students. As for student members, they should play their modeling role to encourage fellows to join in the party; to study hard about party's advancing theories and professional knowledge and to care and help classmates to solve problems in study and life in order to motivate the whole class, grade or school to form a good study atmosphere [8].

\section{Multichannel For Carrying Forward The Models}

In the party construction and building of style of study, it's necessary to discover outstanding people at ordinary work and representatives of teachers and students with fine instructional and learning style. An example can be set via mass media such as internet, magazines and newspaper to display the modeling effect on all to stimulate costiveness of teachers and students to practice in building style of study. 


\section{E. The Perfection of Cultural Construction at School}

The Socialist Core Values can be spread to teachers and students through internet, bulletin board and broadcast to instruct them to learn national policies and regulations of their accord, which enable to improve the political quality of teachers and students effectively as well as to build well study atmosphere. Moreover, information of technical competitions from home and abroad should be available for teachers and students to inspire teachers to enhance their academic quality to provide a better instruction for students; meanwhile, students are encouraged to participate in more competitions beyond school, which can not only broaden their horizons, but also can benefit them to learn cultural knowledge systematically and comprehensively from the view of profession. With organizations of all kinds of technical and cultural activities, students are attracted to engage in campus activities in which they can realize their weakness and further trigger their motivations of self-study.

\section{F. Enhance the Building of Teachers' Morality}

As Deng Xiaoping, one of the former principal leaders of China, pointed out that' It's the quality of a faculty team that can verify whether an academic institution can foster eligible talents and cultivate learned labor with all-round development of morality, intelligence and physique and socialism awareness for socialism construction.', teacher stands at a critical position for its responsibility of shaping soul, life and personality. President $\mathrm{Xi}$ Jinping emphasized the morality construction when mentioning the standards for an eligible teacher at his speech to teachers and students representatives of BNU Beijing Normal University. At the conference on colleges' ideological politics, president Xi Jinping firstly stressed the enhancement of teachers' morality construction, from which teachers' morality construction is regarded as an important factor and key to style of study building. With the principles to passionate in the job, to be a model for others, to educate with virtue, to help with kindness, teachers should instruct students with moral pursuit, image and emotion to help them become resourceful talents who have ability, love and willingness for study.

\section{CONCLUSION}

The closely relationship between learning-oriented party organization and style of study building symbolizes the well combination between constructions of party and education and makes a good contribution to academic atmosphere building. The learning-oriented party guides the style of study building is the same as the theory guides practice and is beneficial to improve the ideological awareness of teachers and students; while the results of style of study building also enrich research results of the party's theories in return. By strengthening party's advantages through multi-channels and enhance party's leading can style of study building get a bright way to promote style of teaching and studying, to increase the significance of study in college development and student's growth and to motivate students and teachers to form a habit of lifelong learning.

\section{REFERENCES}

[1] Gao Xiangjie, Gao Yinling, Ma Rongjuan. On Party Member Learning in Grassroots Party Organizations Based on Learning Community Theory [J].Journal of Hebei Youth Administrative Cadres college,2018,(30)4:30-34. (In Chinese)

[2] http://baike.baidu.com/item/ Opinions on Promoting the Construction of Learning Party Organizations. (In Chinese)

[3] Guo Liang, Ying Jianwen. On the Ways of Party Students' Role in the Construction of Academic Atmosphere [J].Journal of Hubei Correspondence University, 2011, (24)4: 56-57. (In Chinese)

[4] Li Dengfeng. Thoughts on Promoting the Construction of Study Style by Student Party Construction in Polytechnic Colleges [J].Higher Education Forum,2009,(10)10:36-38. (In Chinese)

[5] Hou Jiagang, Shan Xianguang. Research and Countermeasures on the Construction of College Students' Style of Study under the Impact of Network [J].China Adult Education,2017,8:74-77. (In Chinese)

[6] Zhu Rong. On the Effectiveness of Establishing Learning Grassroots Party Organizations to Promote the Construction of Academic Atmosphere in Colleges and Universities [J].Education Forum, 2011(20):78-80. (In Chinese)

[7] Lv Yanming. Research on the Current Situation and Countermeasures of the Construction of Academic Atmosphere in Contemporary Universities-Based on the Investigation of Ten Universities in Guangzhou Higher Education Mega Center [J].Journal of Hubei Correspondence University, 2018, 8:5-8. (In Chinese)

[8] Xu Xiaogang. On the Path of College Students' Study Style Construction Based on People-oriented Concept [J].China Adult Education, 2018, 8:71-73. (In Chinese)

[9] Yang Xu, Zang Jiangfeng, Chen Yuqun. On the Exemplary Role of College Party Members and Teachers in the Construction of Teaching Style and Study Style [J].Science \& Technology Information, 2010, (34):239. (In Chinese) 